www.journal.univetbantara.ac.id/index.php/ijimm

\title{
Peningkatan Prestasi Belajar Fiqih Materi Jinayah melalui Metode Index Card Match
}

\author{
Mahsun Alwa'id \\ MAN 1 SEMARANG \\ Email: mahsunalwaid@gmail.com
}

\begin{abstract}
Abstrak
Penelitian ini merupakan upaya untuk meningkatkan prestasi belajar Fiqih materi Jinayah dengan metode Index card match di kelas XI IIS 2 MAN 1 Semarang. Pertanyaan utama yang ingin dijawab melalui penelitian ini adalah, apakah penerapan metode Index Card Match dapat meningkatkan prestasi belajar siswa dalam mata pelajaran Fiqih materi Jinayah pada kelas XI IIS 2 MAN 1 Semarang, kabupaten Semarang? Untuk menjawab pertanyaan tersebut maka penelitian ini menggunakan metode Penelitian Tindakan Kelas. Penelitian ini termasuk Penilitian Tindakan Kelas(Classroom Action Reaserch). Subjek Penelitian adalah siswa kelas XI IIS 2 MAN 1 Semarang, kabupaten Semarang Tahun Pelajaran 2018/2019 berjumlah 23 siswa. Teknik pelaksanaan diawali dari pengumpulan data yang meliputi dokumentasi, tes, dan pengamatan serta dianalisa secara deskriptif dan kualitatif. Tindakan dilanjutkan dengan pelaksanaan dua siklus/tahap. Setiap tindakan terdiri atas perencanaan, pelaksanaan, pengamatan/observasi, dan refleksi yang dilaksanakan bersama seorang rekan kerja yang membantu pelaksanaan penelitian. Hasil penelitian menunjukkan bahwa prestasi belajar siswa meningkat dari $56,52 \%$ pada pra siklus menjadi $78,26 \%$ pada siklus I, serta $86,97 \%$ pada siklus II. Perhatian siswa terhadap mata pelajaran juga meningkat dari 43,46\% menjadi $86,96 \%$ pada siklus II. Hasil penelitian ini dapat disimpulkan bahwa penerapan metode Index Card Match dapat meningkatkan prestasi belajar Fiqih pada siswa XI IIS 2 MAN 1 Semarang.
\end{abstract}

Kata kunci: Prestasi Belajar, fiqih, metode index card match.

\section{Improving Fiqih Learning Achievement on Jinayah Material through Index Card Match Method}

\author{
Mahsun Alwa'id \\ MAN 1 Semarang \\ Email: mahsunalwaid@gmail.com
}

\begin{abstract}
This research is effort to improve Fiqih Learning Achievement in Material of Jinayah with Card Match Index Method to students of MAN 1 Semarang Regency Grade XI IIS 2 in 2018/2019. The first question which is answered through this research is whether the assemble of Card Match Index Method can be able to improve Achievement to Learning The Material of Fiqih (Jinayah) to the students of MAN 1 Semarang Regency grade XI IIS 2 in 2018/2019?. To answer this question, so the research use Classroom Action Research Method.

This research include in Classroom Action Research Method. The subject of this research is the students of MAN 1 Semarang regency Grade XI IIS 2 in 2018/2019 amount 23 students. The implementation technique is started from collect the data include: Dokumentation, Test, and Observation that is analyzed in Descriptive and Qualitative. This action continue with two siklus implementation, every action divide into: Planning, action, Observation and Reflection which is done with a partner whom help the research.

The result of research show the students achievement increase from 56,52\% in pra siklus to 78,26\% in one siklus, and then $86,97 \%$ in two siklus. The attention of students with this object can increase, from $43,46 \%$ to $86,96 \%$ in two siklus. The result of research can be concluded that the application of Card Match Index Method can be able to improve Fiqih Learning Achievement to the students MAN 1 Semarang Regency Grade XI IIS 2 in 2018/2019.
\end{abstract}

Keywords: Learning Achievements, Fiqih, Index Card Match Method 
www.journal.univetbantara.ac.id/index.php/ijimm

\section{PENDAHULUAN}

Pendidikan pada dasarnya merupakan salah satu hal yang sangat penting dalam kehidupan manusia. Gerakan peningkatan mutu pendidikan pada hakekatnya memiliki tujuan akhir yaitu meningkatkan mutu hasil penyelenggaraan pendidikan melalui peningkatan kinerja semua komponen, baik komponen siswa, guru, sarana prasarana maupun sistem pembelajaran. Menurut Murphy (1992: 10) upaya memperbaiki dan meningkatkan mutu pendidikan seakan tidak pernah berhenti. Banyak agenda reformasi yang telah, sedang, dan akan dilaksanakan. Beragam program inovatif ikut serta memeriahkan reformasi pendidikan. Reformasi pendidikan adalah restrukturisasi pendidikan, yakni memperbaiki pola hubungan sekolah dengan lingkungannya dan dengan pemerintah, pola pengembangan perencanaan serta pola pengembangan manajerialnya, pemberdayaan guru dan restrukturisasi model-model pembelajaran (Abdul Majid, 2006: 3).

Kegiatan pendidikan tidak lepas dari adanya pendidik dan anak didik. Selain penguasaan dan pemahaman guru dan siswa terhadap kurikulum yang digunakan, diperlukan pula adanya pendekatan metode belajar mengajar yang bervariasi (Abdullah Munir, 2010:80). Karena jika metode yang digunakan monoton atau tetap akan menyebabkan siswa menjadi bosan dan tidak tertarik pada materi pelajaran tersebut. Jika hal ini dibiarkan lama kelamaan akan menambah masalah dan menghambat proses kegiatan belajar mengajar.

Guru tidak cukup dengan memberikan ceramah di depan kelas, hal ini tidak berarti bahwa metode ceramah tidak baik, melainkan pada suatu saat siswa akan menjadi bosan apabila hanya guru sendiri yang berbicara (aktif) sedangkan siswa hanya datang, duduk, mendengar atau pasif. Sikap siswa yang demikian dan selalu jenuh tentu tidak akan dapat menerima pelajaran dengan baik yang akhirnya daya serap siswa rendah.

Kondisi seperti ini tidak akan menumbuh kembangkan kemampuan dan aktifitas siswa seperti yang diharapkan. Misalnya nilai ulangan siswa rendah karena tingkat pemahaman terhadap materi yang dipelajari masih sangat kurang, sehingga guru harus mengulangi pembahasan materi itu lagi. Kegiatan pembelajaran seperti ini tidak efektif dan efisien. Banyak metode yang bisa digunakan dalam kegiatan belajar mengajar, namun tidak semuanya mampu mewujudkan belajar yang bermakna (meaning learning) apabila kurang tepat dalam penggunaannya. Dengan belajar yang bermakna siswa akan lebih tahu dan memahami tentang hal-hal yang dipelajari.

Salah satu metode yang dapat digunakan dalam kegiatan belajar mengajar adalah dengan Index Card Match. Menurut Hisyam Zaini, (2007: 69) Index Card Match adalah strategi yang cukup menyenangkan yang digunakan untuk mengulang materi yang telah diberikan sebelumnya. 
Namun demikian, materi baru pun tetap bisa diajarkan dengan strategi ini dengan catatan, siswa diberi tugas mempelajari topik yang akan diajarkan terlebih dahulu, sehingga ketika masuk kelas mereka sudah memiliki bekal pengetahuan. Metode Index Card Match dapat menciptakan pembelajaran yang menyenangkan sehingga siswa dapat meningkatkan pemahaman terhadap apa yang sedang dipelajari (Marwan, 2012:04).

Berdasarkan pengamatan awal terhadap pelaksanaan dan hasil pembelajaran fiqih di MAN 1 Semarang Kabupaten Semarang, ditemukan beberapa permasalahan, diantaranya: pertama, pembelajaran selama ini masih cenderung monoton dan belum divariasikan dengan metode lain yang lebih variatif, misalnya yang memperhatikan perbedaan individual peserta didik. Hal ini menyebabkan aktivitas peserta didik rendah atau pasif. Kedua, prestasi belajar masih rendah, hal ini dibuktikan dari hasil evaluasi belajar kelas XI IIS 2 yang berjumlah 23 peserta didik, sebanyak 10 atau sekitar 43,47\% belum berhasil mendapatkan nilai 75 sebagai kriteria ketuntasan minimal (KKM) yang telah ditetapkan.

Tujuan pendidikan yang ingin dicapai dikategorikan menjadi tiga bidang, yakni bidang kognitif, afektif dan psikomotorik. Sebagai tujuan yang hendak dicapai ketiga-tiganya harus nampak sebagai prestasi belajar siswa. Oleh karena itu ketiga aspek tersebut dipandang sebagai prestasi belajar dari proses pengajaran yang nampak dalam perubahan tingkah laku. Secara teknik dirumuskan dalam sebuah pernyataan verbal melalui tujuan pengajaran (tujuan instruksional) (Sudjana, 2005: 49).

\section{METODE}

Penelitian ini menggunakan Penelitian Tindakan Kelas (PTK). PTK merupakan suatu pencermatan terhadap kegiatan belajar berupa sebuah tindakan yang sengaja dimunculkan dan terjadi dalam sebuah kelas besar secara bersama. Tindakan tersebut diberikan oleh guru atau dengan arahan dari guru yang dilakukan oleh siswa (Arikunto, 2008: 3). Maka sesuai dengan jenis penilitian yang dipakai yaitu penelitian tindakan, penelitian diawali dengan perencanaan tindakan (planning), penerapan tindakan (action), mengobservasi dan mengevaluasi proses dan prestasi tindakan (observation and evaluation), dan melakukan refleksi (reflektif) (Supardi, 2008: 104). Observasi dibagi menjadi dua siklus yaitu, siklus I dan II dimana masing-masing siklus memiliki alur kegiatan yang sama dan membahas satu sub pokok bahasan yang diakhiri dengan tes formatif diakhir masing-masing siklus. Dibuat dua siklus dengan maksud untuk memperbaiki system pengajaran yang telah dilaksanakan.

Perencanaan kegiatannya meliputi membuat rencana atau scenario pelaksaan pembelajaran 
menggunakan metode Index Card Match, mempersiapkan fasilitas dan sarana pendukung , mempersiapkan lembar observasi guru untuk mengetahui kinerja guru, Perencanaan tindakan pembelajaran, dan menyiapkan instrumen untuk menggali data hasil belajar siswa dengan menggunakan tes evaluasi.

Pelaksanaan merupakan tahapan pengaplikasian semua perencanaan tindakan yang telah disusun meliputi guru menjelaskan kepada siswa tentang materi yang akan disampaikan dalam proses pembelajaran dengan menggurakan metode Index Card Match,guru membagikan potonganpotongan kertas yang berisi pertanyaan dan potongan-potongan kertas lain yang berisi jawaban kepada semua siswa, siswa mencari pasangannya masing-masing yang sesuai dengan pertanyaan dan jawaban, kemudian meteka duduk berdekatan, kemudian setiap pasangan secara bergantian membacakan soal yang diperoleh dengan suara keras kepada teman-teman lainnya. Selanjutnya soal tersebut dijawab oleh pasangannya,demikian seterusnya dan selanjutnya guru memberi kesempatan kepada siswa untuk bertanya maupun mengutarakan pendapatnya, kemudian guru memberikan tugas berupa latihan soal yang sesuai dengan materi yang telah disampaikan.

\section{Observasi atau Pengamatan}

Observasi adalah kegiatan pengamatan (pengambilan data) untuk memotret seberapa jauh efek tindakan kelas mencapai sasaran (Supardi,2008: 127) yaitu dengan lembar observasi. Observasi dalam penelitian tindakan kelas merupakan pengamatan yang dilakukan oleh peneliti untuk menggali data yang dilakukan dengan cara mengamati guru pada proses pembelajaran dengan menggunakan lembar observasi guru. Selain itu dilakukan tes evaluasi untuk menggali data siswa.

\section{Refleksi}

Refleksi digunakan untuk mengukur keberhasilan suatu siklus dan dilakukan setiap akhir siklus. Kegiatan ini untuk melihat keberhasilan dan kelemahan dari perencanaan yang dilaksanakan sebelumnya. Refleksi juga menjadi acuan dalam menentukan perbaikan atas kelemahan pelaksanaan siklus sebelumnya untuk diterapkan pada siklus berikutnya.

Pada penelitian ini populasinya adalah seluruh siswa kelas XI MAN 1 Semarang sedangkan sampel penelitian adalah kelas XI IIS 2 yang memiliki rata-rata minat dan hasil belajar rendah. Sebelum pelaksanaan penelitian diperoleh data nilai ulangan harian siswa kelas XI IIS 2 MAN 1 Semarang Kabupaten Semarang pada mata pelajaran Fiqih. Dari 23 siswa, yang terdiri dari 19 siswa perempuan dan 4 siswa laki-laki, hasil belajar siswa belum memuaskan nilai rata-rata kelas yaitu 69,04\% dan masih ada sekitar 10 siswa dengan rentang nilai 50-65 dan nilainya masih dibawah Kriteria Ketuntasan Minimal (KKM) yaitu 75. 


\section{HASIL DAN PEMBAHASAN}

Hasil penelitian ini menunjukkan tentang hasil belajar siswa yang terdiri atas respon perhatian, keaktifan, dan hasil belajar siswa. Keaktifian siswa ini meliputi: menjawab pertanyaan, bertanya, mengemukakan pendapat, dan mengerjakan latihan soal. Pada pra siklus diperoleh perhatian siswa diketahui yang merespon terhadap proses pembelajaran rata-ratanya $56,52 \%$, sedangkan yang tidak merespon 43,48 \%. Menurut kategori perhatian berarti siswa dalam mengikuti proses pembelajaran cukup memperhatikan.

Pada siklus I diperoleh hasil belajar siswa cukup baik, nilai rata- rata kelas yaitu 74,26 nilainya sudah mencapai Kriteria Ketuntasan Minimal (KKM), hasil tersebut menunjukkan bahwa pada siklus I ini ketuntasan belajar secara klasikal belum tercapai yaitu $85 \%$ tetapi menunjukkan adanya peningkatan, walaupun masih ada 5 siswa. Dari pada siklus I ini sudah menunjukkan adanya peningkatan hasil belajar yang cukup baik. Selama proses pembelajaran di kelas beberapa siswa sudah aktif memperhatikan, sudah ada siswa yang berani bertanya, menjawab pertanyaan serta mengemukakan pendapat. Namun sebagian siswa masih kurang memperhatikan sehingga hasilnya kurang maksimal.

Pada siklus II diperoleh hasil bahwa perhatian siswa, diketahui yang merespon terhadap proses pembelajaran rata-ratanya $86,96 \%$, sedangkan yang tidak merespon $13,04 \%$. Hasil belajar siswa sudah sangat baik dengan rata-ratanya 86,10 hasil tersebut mengalami peningkatan bila dibandingkan dengan siklus I. Hasil nilai belajar ini menunjukkan adanya ketuntasan belajar yang mencapai $86,95 \%$, atau sekitar 20 siswa yang tuntas belajar Dari siklus II ini sudah menunjukkan hasil yang baik dan sudah mencapai ketuntasan klasikal yaitu 85\%. Siswa sudah memperhatikan yang dibuktikan dengan keaktifan bertanya, mengemukakan pendapat, serta menjawab pertanyaan.

Melalui hasil penelitian ini menunjukkan bahwa cara belajar dengan menggunakan strategi Active Learning yang menerapkan metode Index Card Match memiliki dampak positif dalam meningkatkan prestasi belajar siswa. Hal ini dapat dilihat dari semakin meningkat dan mantapnya pemahaman siswa terhadap materi yang disampaikan guru.

Dalam rangka mengetahui hasil, maka penelitian dilakukan minimal dua siklus. Pra Siklus dilihat sebagai gambaran bahwa metode konvensional perlu diperbaiki supaya hasil belajar siswa bisa mencapai hasil yang maksimal. Dengan metode konvensional pembelajaran hanya berpusat pada guru yang menggunakan metode ceramah saja, maka hal tersebut membuat suasana membosankan 
sehingga anak cenderung akan mencari kesibukan sendiri - sendiri tanpa memperhatikan kepada guru. Salah satunya adalah dengan bicara sendiri sehingga membuat suasana menjadi gaduh. Hanya ada beberapa anak yang mau memperhatikan keterangan dari guru.

Tabel 1. Hasil Gabungan Perhatian Siswa

\begin{tabular}{ccc}
\hline SIKLUS & JUMLAH & PERSENTASE \\
\hline I & 13 & $56,52 \%$ \\
II & 20 & $86,96 \%$ \\
\hline
\end{tabular}

Tabel 2. Gabungan Hasil Belajar

\begin{tabular}{ccccc}
\hline \multirow{2}{*}{ SIKLUS } & \multicolumn{2}{c}{ HASIL BELAJAR } & \multicolumn{2}{c}{$\begin{array}{c}\text { PERSENASE } \\
\text { Tidak Tuntas }\end{array}$} \\
\hline Pra Siklus & 1588 & 69,04 & $56,53 \%$ & $43,47 \%$ \\
I & 1708 & 74,26 & $78,26 \%$ & $21,74 \%$ \\
II & 1980 & 86,09 & $86,97 \%$ & 13,91 \\
\hline
\end{tabular}

\section{SIMPULAN DAN SARAN}

Berdasarkan hasil penelitian kegiatan pembelajaran yang dilakukan pada siklus I dan II bahwa perhatian, keaktifan, dan hasil belajar pada mata pelajaran Fiqih dengan menerapkan metode Index Card Match, dapat disimpulkan sebagai berikut: Penerapan metode Index Card Match dapat meningkatkan prestasi belajar siswa kelas XI MAN 1 Semarang kabupaten Semarang tahun pelajaran 2016/2017, hal tersebut dapat dilihat pada proses belajar mengajar dari 23 siswa yang telah mencapai KKM sebesar $56,52 \%$ pada pra siklus meningkat menjadi $78,28 \%$ pada siklus I dan $86,97 \%$ pada siklus II.

\section{DAFTAR REFERENSI}

Ahmadi, Abu dan Widodo Supriyono.1991.Psikologi Belajar.Jakarta: PT. Rineka Cipta.

Arief, Armai . 2002. Pengantar Ilmu dan Metodologi Pendidikan Islam. Jakarta : Ciputat Pers.

Arikunto, Suharsimi. 2008. Penelitian Tindakan Kelas. Jakarta : Bumi Aksara

Ash-Shiddiqiy, Hasby. 1999. Pengantar Ilmu Fikih. Semarang. PT. Pustaka Riska Putra.

Baharudin, Wahyuni Nur Esa. 2008. Teori Belajar dan Pembelajaran. Yogyakarta: Ar-Ruz Media

Bahri Djamhara, Saiful. 2002. Psikologi Belajar. Jakarta : PT Rineka Cipta.

Bakry, Nazar Sidi. 2003. Fikih dan Ushul Fikih. Jakarta: PT. Raja Grafindo Persada.

Dalyono, M. 2001. Psikologi Pendidikan. Jakarta : Robbani Press.

Hanafi, A. 1989. Pengantar dan Syarah Hukum Islam. Jakarta: PT. Bulan Bintang. Nusantara. 
www.journal.univetbantara.ac.id/index.php/ijimm

Ismail, SM. 2008. Strategi Pembelajaran Ilmu Agama Islam Berbasis PAIKEM.. Jakarta : Rasail Media Group.

Pribadi, Benny A. 2009. Model Desain Sistem Pembelajaran. Jakarta: PT. Dian Rakyat.

Poerwardarminta, 2006, Kamus Umum Bahasa Indonesia, Jakarta : Balai Pustaka.

Purwanto, Ngalim. 2003. Psycologi Pendidikan. Bandung: PT. Remaja Rosdakarya

Sanjaya, Wina. 2006. Strategi Pembelajaran Berorientasi Standar Proses

Pendidikan. Jakarta : Kencana Predana Media.

Siberman, Mell. 2006. Active Learning: 101 Cara Belajar Siswa Aktif. Bandung :

Standar Nasional Pendidikan beserta Delapan Peraturan-peraturan Menteri Pendidikan Nasional. 2009. Yogyakarta : CV Karya Mulia.

Sudjana, Nana. 2005. Dasar-Dasar Proses Belajar Mengajar. Bandung : Sinar Baru Algesindo Ofset.

Sukardi, 2005, Metodologi Penelitian Pendidikan Kompetensi dan Praktiknya, Jakarta : Sinar Grafika Offset.

Suryabrata, Sumadi, 2005, Psikologi Pendidikan, Jakarta : PT Raja Grafindo Persada. Syah, Muhibbin. 2003. Psikologi Belajar. Jakarta: PT Raja Grafindo Persada.

Supardi, 2008, Penelitian Tindakan Kelas (Classroom Action Research) Beserta Sistematika Proposal dan Laporannya, Jakarta : Bumi Aksara.

Usman, Uzzer, Lilis Setiawati. 1993. Upaya Optimalisasi Kegiatan Belajar Mengajar. Bandung : PT Remaja Rosdakarya 